\title{
MAJOR GOAT MILK PROTEIN: SEPARATION AND CHARACTERIZATION BY “LAB-ON-A-CHIP” MICROFLUIDIC ELECTROPHORESIS
}

\author{
ALESSA SIQUEIRA DE O. DOS SANTOS ${ }^{1}$ \\ VANEIDA MARIA MEURER ${ }^{2}$ \\ FABIANO FREIRE COSTA ${ }^{2}$ \\ IGOR MOURA DE PAIVA ${ }^{2}$ \\ GISELE NOGUEIRA FOGAÇA ${ }^{1}$ \\ ANTÔNIO SILVIO DO EGITO ${ }^{3}$ \\ MARCO ANTONIO MOREIRA FURTADO ${ }^{2}$ \\ MARTA FONSECA MARTINS ${ }^{1}$.
}

\begin{abstract}
This work presents the electrophoretic profile of goat and cow milk samples and their mixtures using microfluidic and conventional electrophoresis. The microfluidic method allowed the separation of the major caseins from milk, excepting the goat $\mathrm{K}$-casein. Besides, the major whey proteins were separated with perfect distinction of $A$ and $B \beta$-lactoglobulin variants. Comparing to SDS-PAGE, a variation in the molecular weight was observed in all milk proteins. However, $A$ and $B \quad \beta$-lactoglobulin variants could not be isolated using SDSPAGE. Although urea-PAGE did not show high resolution among whey proteins, $\gamma^{-}, \mathrm{K}-, \beta-$, and $\alpha$-caseins were clearly identified. This method also showed a lower limit detection of cow milk in mixture samples than the "lab-on-a-chip" electrophoresis. In both methods, the highest linearity obtained from plotting total percentage against cow milk concentration was observed by using cow $\alpha_{\mathrm{s} 1}$-casein $\left(R^{2}=0.986\right.$ and $\left.R^{2}=0.973\right)$. This result indicates that microfluidic electrophoresis is an effective tool to detect the presence of some proteins in goat and cow milk, and in mixtures. Microfluidic chip technology might will complement the current methods for analyzing milk proteins, highlighting its speed amount of reagents and whey protein separation, which showed a better result than urea or SDSPAGE.
\end{abstract}

1 Embrapa Dairy Cattle Research Center. Juiz de Fora/MG, Brazil. E-mail author for correspondence: alessa.siqueira@gmail.com

2 Federal University of Juiz de Fora. Faculty of Pharmacy. Juiz de Fora/MG, Brazil

3 Embrapa Goats and Sheep Research Center. Sobral/CE, Brazil. 


\section{INTRODUCTION}

Milk proteins components are often classified into four groups, according to their physicochemical and structural properties: caseins, whey proteins, milk fat globule membrane (MFGM), and enzymes (Sgarbieri, 2005). The separation and quantification of each of these proteins is an important research subject, as a source of qualitative and quantitative data in studies about the quality of milk and dairy products, as well as in the evaluation of these products (Mayer et al., 2012). Polyacrylamide gel electrophoresis (PAGE) under reducing conditions in the presence of urea (urea-PAGE) (Veloso et al., 2002; Egito et al., 2006) or of sodium dodecyl sulphate (SDSPAGE) (Creamer and Richardson, 1984; Patel et al., 2007; Anema, 2009) is considered an important separation technique. It affords to identify and quantify milk proteins.

In recent years, other methods have been used to analyze casein fractions, like isolectric focusing (IEF), ion-exchange high-performance liquid chromatography (HPLC) (Dziuba et al., 2001), reverse-phase modes and gel filtration, immunological techniques, and capillary electrophoresis (Veloso et al., 2002). More recently, microfluidic chip electrophoresis has been used to quantify DNA and RNA, and to separate and quantify proteins in proteomic studies as well as in the development of medical drugs and diagnosis (Poitevin et al., 2009; Li et al., 2010).

The advantages of the technique include reliable results, optimization of analysis and sample preparation times, small amounts of chemicals required, and a nanogram detection limit of proteins (per $\mu \mathrm{L}$ ) (Goetz et al., 2004; Butikofer et al., 2006; Wu et al., 2008). Research efforts are currently directed to evaluate the potential applicability of the technique in the assessment of the distribution of cow milk protein fractions (Anema, 2009) and characterization of the major whey proteins from milk of Mediterranean water buffalo (Buffoni et al., 2011). To the best of our knowledge, the characterization of cow and goat milk protein by using microfluidic chip electrophoresis is still poorly explored. Besides, there is no published data available in the literature so far about the electrophoretic profile of cow and goat mixtures. In this sense, the present study evaluates the use of microfluidic electrophoresis in the routine analysis of proteins in cow and in goat milk. We compared the protein profiles of goat milk supplemented with different amounts of cow milk using conventional electrophoresis (urea-PAGE and SDS-PAGE) and microfluidic electrophoresis.

\section{MATERIAL AND METHODS}

\subsection{MILK SAMPLES PREPARATION}

Fresh goat milk was collected in the Saanen goat farming unit and fresh Holsteincow milk was obtained in the José Henrique Bruschi Experimental Station of Embrapa Dairy Cattle, in Coronel Pacheco, Minas Gerais, Brazil. The mixtures were prepared using goat milk and a concentration gradient of cow milk $(0,2,4,6,8,10,20,35,50$, and $100 \mathrm{v} / \mathrm{v})$. Samples were immediately frozen and kept at $-20^{\circ} \mathrm{C}$ until analysis.

\subsection{TOTAL PROTEIN DETERMINATION}

Proteins were quantified according to the Bradford method (Bradford, 1976) using Coomassie brilliant blue (CBB, Bio-Rad\#500-006) following the manufacturer's instructions. The standard protein solution (BSA, Sigma) was prepared and serially diluted in ultrapure water (in the $200 \mu \mathrm{g} / \mathrm{mL}-2,000 \mu \mathrm{g} / \mathrm{mL}$ range) to construct a standard curve. Proteins levels were determined to prepare the standard curve in BSA. The standard curve of milk samples was constructed following the conventional method, which recommends the minimum volume of $4 \mu \mathrm{L}$ of standards and samples in $200 \mu \mathrm{L}$ of diluted CBB. Milk samples were previously diluted to 1:25 in ultrapure water. Absorbance was measured after $5 \mathrm{~min}$ incubation period at room temperature. Peaks were measured under UV light at $595 \mathrm{~nm}$ in the "Protein Bradford" module in a spectrometer NanoDrop ${ }^{\mathrm{TM}}$ ND-1000. 


\subsection{MICROFLUIDIC CHIP ELECTROPHORESIS}

Microfluidic chip electrophoresis was conducted in the Agilent 2011 Bioanalyzer with the 2100 Expert Software and the protein kit 80 (Agilent Technologies, Waldbronn, Germany). The denaturing solution used to reproduce the reducing condition was prepared adding $3.5 \%$ (vol.) of 1 mol L-1 dithiothreitol (DTT) to the sample buffer. Fresh milk samples of cow and goat and the mixtures were previously prepared using a protein separation buffer with $6 \mathrm{~mol} \mathrm{~L}^{-1}$ of urea (Gouldsworthy et al., 1990; Costa et al., 2014). Commercial standard proteins $\alpha_{s 1}$-casein $\left(\alpha_{s 1}-C N\right), \beta$-casein $(\beta-C N)$, $\kappa$-casein $(\kappa-C N), \beta$-lactoglobulin ( $\beta$-LG), and $\alpha$-lactalbumin ( $\alpha$-LA) (Sigma-Aldrich, St. Louis, MO, USA) were prepared as $1 \mathrm{mg} \mathrm{mL}^{-1}$ solutions. The automated data analysis was conducted using the software Agilent 2100 Expert, which determined molecular weight and quantitative parameters as

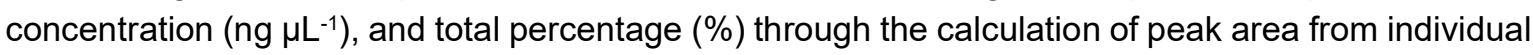
proteins in the sample.

\subsection{SODIUM DODECYL SULPHATE POLYACRYLAMIDE GEL ELECTROPHORESIS (SDS-PAGE)}

SDS-PAGE was carried out under denaturing conditions in the vertical electrophoresis system (Z352802-1EA Sigma-Aldrich, St. Louis, MO, USA) (Pereira, 2003; Egito et al., 2006). The stacking gel was prepared with $4.9 \%(\mathrm{w} / \mathrm{v})$ acrylamide/bis in $0.5 \mathrm{~mol} \mathrm{~L}^{-1} \mathrm{Tris}-\mathrm{HCl}$ buffer, $\mathrm{pH} 6.8$, and $10 \%$ SDS. The separation gel was prepared with $12.5 \%(\mathrm{w} / \mathrm{v})$ acrylamide/bis in $1.5 \mathrm{~mol} \mathrm{~L}{ }^{-1} \mathrm{Tris}-\mathrm{HCl}, \mathrm{pH} 8.8$, and $10 \%$ SDS. Previously, samples were diluted to $1: 34$ in sample buffer solution $\left(0.5 \mathrm{~mol} \mathrm{~L}^{-1}\right.$ Tris- $\mathrm{HCl}$ buffer, $\mathrm{pH} 6.8$, and $10 \%$ SDS w/v, $0.024 \mathrm{~mol} \mathrm{~L}^{-1} \beta$-mercaptoethanol, $0.22 \mathrm{mmol}^{-1}$ bromophenol blue) and heated. The molecular weight ladder Novex Protein (Life Technologies), commercial standard proteins (Sigma-Aldrich, St. Louis, MO, USA) $\alpha_{\mathrm{s} 1}-\mathrm{CN}, \beta-\mathrm{CN}, \kappa-\mathrm{CN}, \beta-\mathrm{LG}$ and $\alpha$-LA. Solutions (10 mg mL-1) of each individual protein were prepared by adding to purified water (Ultrapure Milli-Q; Millipore Corp., USA) and stirring until dissolved. Individual protein standards were dissolved in buffer solution (0.5 mol L-1 Tris- $\mathrm{HCl}$ buffer, $\mathrm{pH} 6.8$, and $10 \%$ SDS w/v, $0.024 \mathrm{~mol} \mathrm{~L}^{-1} \beta$-mercaptoethanol, $0.22 \mathrm{mmol} \mathrm{L}^{-1}$ bromophenol blue) and prepared with final concentration of $2 \mathrm{mg} \mathrm{mL}^{-1}$.

After heating at $100^{\circ} \mathrm{C}$ for $3 \mathrm{~min}, 30 \mu \mathrm{L}$ aliquot of samples were applied onto the gels. Voltage and current on the stacking gel were $80 \mathrm{~V}$ and $40 \mathrm{~mA}$, respectively. Gels were incubated overnight in a staining solution ( $0.1 \%$ Coomassie blue R- $250,50 \%$ ethanol, $2 \%$ trichloroacetic acid) and then in destaining solution ( $25 \%$ ethanol, $10 \%$ acetic acid). Images of gels were scanned (Hewlett Packard Scanjet 2400) and the molecular weight of each protein fraction was estimated using the software Image Quant TL (GE Healthcare Life Science).

\subsection{UREA POLYACRYLAMIDE GEL ELECTROPHORESIS (UREA-PAGE)}

The urea-PAGE analysis was conducted under reducing conditions in a vertical electrophoresis system (Z352802-1EA Sigma-Aldrich, St. Louis, MO, USA) with modifications (Pereira, 2003; Egito et al., 2006). The stacking gel contained $6 \%(\mathrm{~m} / \mathrm{v})$ acrylamide/bis in buffer $(0.03$ mol L-1Tris-HCl, $2.5 \mathrm{~mol} \mathrm{~L}^{-1}$ urea, $\mathrm{pH} 7.6$, while the separation gel included $10 \%(\mathrm{w} / \mathrm{v})$ acrylamide/ bis in $0.26 \mathrm{~mol} \mathrm{~L}^{-1} \mathrm{Tris}-\mathrm{HCl}$ buffer, and $3.2 \mathrm{~mol} \mathrm{~L}^{-1}, \mathrm{pH}$ 8.9. Previously, samples were diluted to $1: 34$ in sample buffer solution $\left(6 \mathrm{mmol} \mathrm{L}-1\right.$ Tris- $\mathrm{HCl}, 0.8 \mathrm{mmol}$ urea, $0.024 \mathrm{~mol} \mathrm{~L}^{-1} \beta$-mercaptoethanol, 0.22 mmol L-1bromophenol blue). $30 \mu \mathrm{L}$ aliquot of diluted samples was applied onto gels. Voltage used in the stacking and separation gels were $250 \mathrm{~V}$ and $280 \mathrm{~V}$, respectively, for $3 \mathrm{~h}$. Gels were incubated overnight in a staining solution ( $0.1 \%$ Comassie blue R-250, $50 \%$ ethanol, $2 \%$ trichloroacetic acid) and then in destaining solution ( $25 \%$ ethanol, $10 \%$ acetic acid). Images of gels were scanned (Hewlett Packard Scanjet 2400) and the integration of peaks from each separated protein was performed using the software Image Quant TL (GE Healthcare Life Science), generating the values of area and total percentage. 


\subsection{STATISTICAL ANALYSIS}

Goat and cow milk samples and their mixtures were applied on chips and gels in triplicate, with three repeats each, according to an unbalanced incomplete block design. The results of the protein fractions were analyzed using quantitative information generated by Image Quant TL and Agilent 2100 Expert. The data obtained from the values of peak area and total protein percentage were analyzed using the software SPSS version 20.0 so that they were plotted against the concentrations of cow milk added to goat milk.

\section{RESULTS AND DISCUSSION}

\subsection{SEPARATION OF THE MAIN COW AND GOAT MILK PROTEINS BY SDS-PAGE}

In Figure 1, proteins from both goat and cow milk were resolved in gel containing sodium dodecyl sulphate (SDS) as well as the major milk proteins and isolated whey protein.

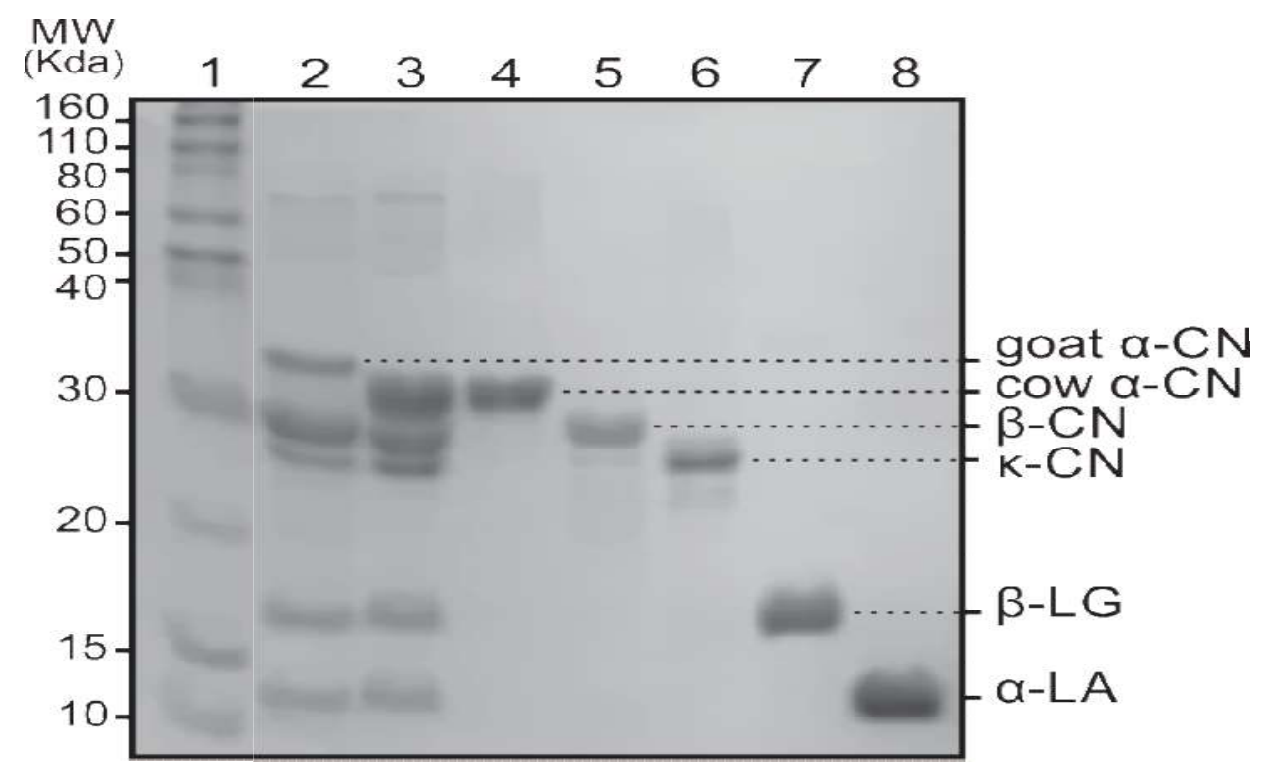

FIGURE 1 - ELECTROPHORETIC PROFILE OF MILK PROTEINS OBTAINED BY SDSPAGE. 1 - MOLECULAR WEIGHT LADDER (NOVEX PROTEIN), 2 - PURE GOAT MILK, 3 - PURE COW MILK, 4 - 8: PURIFIED PROTEINS FROM COW MILK (SIGMA): ALPHACASEIN ( A $11^{-C N}$ ), BETA-CASEIN (B-CN), KAPPA-CASEIN (K-CN), ALPHA-LACTALBUMIN (A-LA), BETA-LACTOGLOBULIN (B-LG).

The analysis of goat and cow milk using the conventional SDS-PAGE is shown in Table 1.

The major caseins in both goat and cow milk produced three fractions, $\alpha_{s}, \beta$, and k-CN. The molecular weight of cow $\alpha_{\mathrm{s} 1}-\mathrm{CN}$ estimated according to elution times of commercial protein standards, was $29.97 \mathrm{kDa}$. It is slightly faster in migration, compared to goat $\alpha_{\mathrm{s} 1}-\mathrm{CN}$, which presents a molecular weight was $30.18 \mathrm{kDa}$ (Table 1 ). Considering that the mobility of goat and cow $\alpha_{\mathrm{s} 1}{ }^{-}$ $\mathrm{CN}$ is different inter-and intraspecie, the genetic polymorphism might be one of the reason for this observation. In fact, several studies have recently reported that, in special, goat milk often exhibit polymorphism, displaying 17 variants (Marletta et al., 2007). Previously published results show that the electrophoretic pattern observed using SDS-PAGE indicates that casein produced two large fractions, $\alpha_{s}-C N$ and $\beta-C N$, the first being the dominant fraction (Salem et al., 2009). However, in goat milk the prevailing fraction was $\beta-C N$. No difference was observed in migration of the main whey proteins, as reported elsewhere (Salem et al., 2009). 


\section{TABLE 1 - SDS-PAGE. ESTIMATED MOLECULAR WEIGHT OF GOAT AND COW MILK PROTEINS}

\begin{tabular}{cccc}
\hline Milk proteins & Goat milk $^{*}$ & Cow milk & Standard proteins \\
\hline$\alpha-$ LA & 12.34 & 12.56 & 12.87 \\
$\beta-$ LG & 16.50 & 16.63 & 17.05 \\
$\kappa-\mathrm{CN}$ & 26.21 & 25.72 & 27.35 \\
$\beta-\mathrm{CN}$ & 28.15 & 28.03 & 28.79 \\
$\alpha_{\mathrm{s} 1}-\mathrm{CN}$ & 30.18 & 29.94 & 29.97 \\
\hline
\end{tabular}

"Molecular weight in $\mathrm{kDa}$

\subsection{SEPARATION OF THE MAJOR CASEINS BY UREA-PAGE IN COW AND GOAT MILK}

\subsubsection{Qualitative Analysis}

The values obtained by the Bradford method were used as a guideline to define sample dilutions. Mean concentration of total proteins was $901.41 \mu \mathrm{g} \mathrm{mL}^{-1}$. The electrophoretic profile and densitograms of pure goat and cow milk and of mixtures obtained by urea-PAGE are shown in Figures $2 \mathrm{~A}$ and $2 \mathrm{~B}$, respectively.

This method afforded to visualize the separation of caseins $\gamma-C N, k-C N, \beta-C N$ and $\alpha-C N$. The best resolved bands corresponded to the major caseins $\beta-C N$ and $\alpha-C N$, both of cow and goat milk (Pardo and Natalucci, 2002; Veloso et al., 2002; Egito et al., 2006). The whey protein fractions were poorly visible in this method (Urbán et al., 2002; Salem et al., 2009; Hinz et al., 2012). The quantitative analysis of goat and cow milk mixtures by urea-PAGE showed that the electrophoretic profile of $\operatorname{cow} \alpha_{\mathrm{s} 1}-\mathrm{CN}$ was different from that of the goat $\alpha_{\mathrm{s} 1}-\mathrm{CN}$, which was also observed for other animal species, such as horses, pigs, camels and humans (Egito et al., 2006).

The migration of goat $\alpha_{\mathrm{s} 1}-\mathrm{CNpresented} \mathrm{lower} \mathrm{relative} \mathrm{mobility} \mathrm{(Rf),} \mathrm{compared} \mathrm{with} \mathrm{the} \mathrm{cow}$ $\alpha_{s 1}-C N$, which migrated more quickly. In light of the similarity of protein profiles of goat and cow milk on SDS-PAGE, the urea-PAGE method is the most appropriate to detect the presence of cow milk in goat milk. The technique was more specific to detect adulteration of goat milk with cow milk, which was also observed for other species (Egito et al., 2006). The analysis of the urea-PAGE gels of goat and cow milk mixtures showed that it is possible to detect the addition of as little as $2 \%$ $(\mathrm{v} / \mathrm{v})$ raw cow milk to raw goat milk, based on the profile of cow $\alpha-C N$. Urea-PAGE carried out with the extraction of sodium caseinate has been used to analyze adulteration of goat milk with cow milk at a concentration of $2.5 \%$ and up (Egito et al., 2006).Other studies have also revealed that the protein profile of cow $\alpha-\mathrm{CN}$ was significantly different from all casein bands used as indicators of adulteration, and reported the capacity of the technique to detect the addition of $5 \%$ cow milk, above the detection limit observed in the present study. The bands of the protein $\beta-\mathrm{CN}$ of both species presented the same electrophoretic pattern, with no band overlapping (Furtado, 1983; Veloso et al., 2002). 


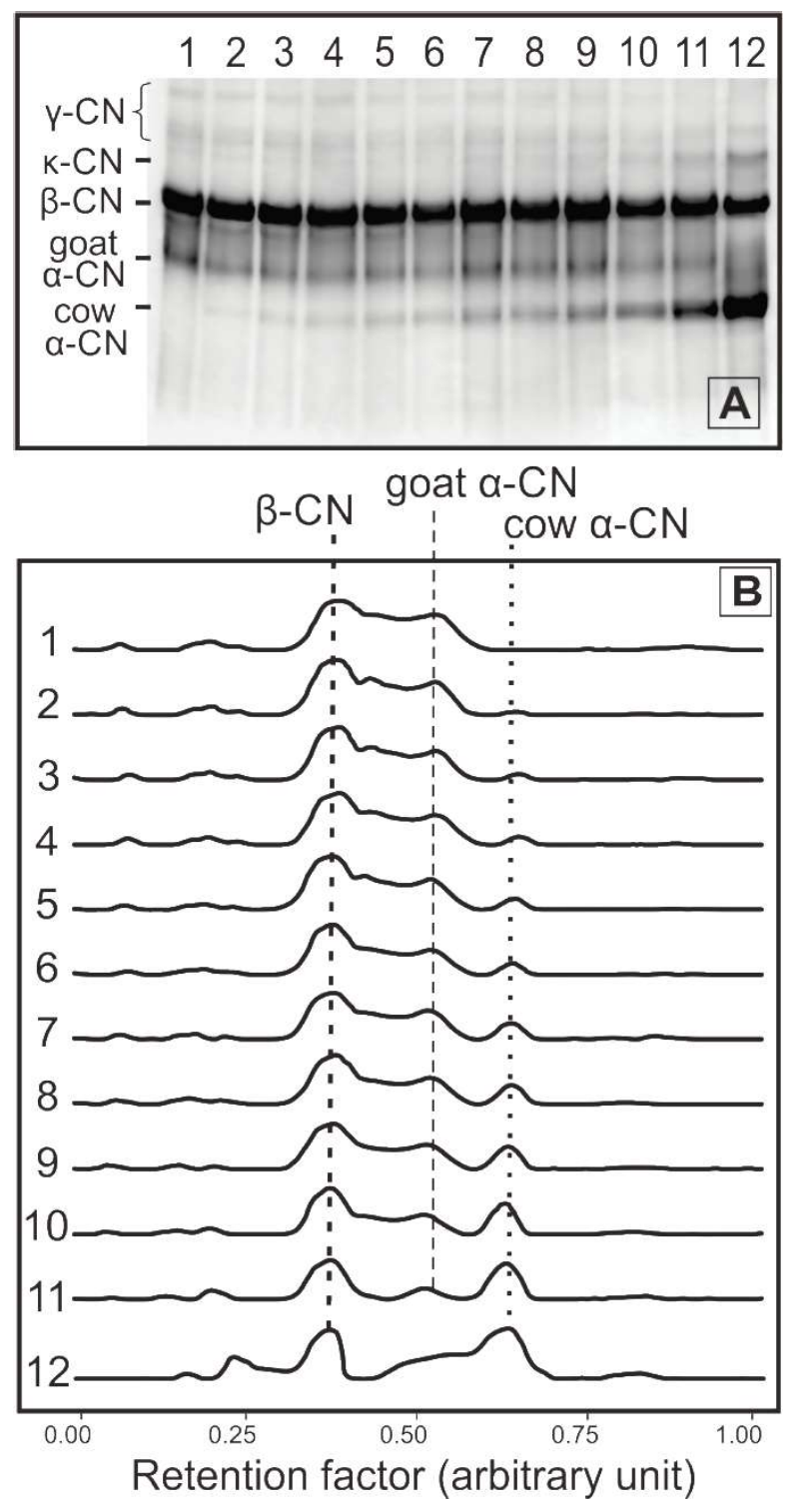

FIGURE 2 - ELECTROPHORETIC PROFILE (A) AND DENSITOGRAM (B) OF PURE AND ADULTERATED SAMPLES OBTAINED BY UREA-PAGE. 1 - PURE GOAT MILK, 12 - PURE COW MILK, 2 - 11: GOAT MILK MIXED AT 2, 4, 6, 8, 10, 12, 15, 20, 35, AND 50\% COW MILK.

\subsubsection{Quantitative Analysis}

The quantitative analysis of the composition of major caseins conducted by densitometry (Figure $2 \mathrm{~B})$ revealed that goat $\beta-\mathrm{CN}$ level was higher than cow $\beta-\mathrm{CN}$ level $(55.83 \%$ and $43.61 \%$, respectively). In turn, cow $\alpha-C N$ was higher than goat $\alpha-C N(56.65 \%$ and $44.25 \%)$. These values agree with percentages observed in other studies (Veloso et al., 2002; Salem et al., 2009). In Goat milk, $\beta$-CN prevailed $(70.2 \%)$, while $\alpha-C N$ was lower $(29.8 \%)$.

The analysis of protein composition of mixtures of goat and cow milk $(2,4,6,8,10,20$, 35 , and $50 \% \mathrm{v} / \mathrm{v}$ ) pointed to decreasing trend for goat $\alpha-\mathrm{CN}$, and to a rising trend for cow $\alpha-\mathrm{CN}$, as observed in the respective bands on gels (Figure 2A), in total percent values and in densitograms (Fig. 2B). Total protein levels in goat milk were lower than in cow milk (between 28 and $32 \mathrm{~g} \mathrm{~L}^{-1}$ in goat milk and 5.8 and $6.5 \mathrm{~g} \mathrm{~L}^{-1}$ in cow milk). $\alpha$-LA, $\beta$-LG and immunoglobulins account for higher proportions in this protein fraction. Caseins were the main components of total proteins, with 22 to 28 $\mathrm{g} \mathrm{L}^{-1}$ in goat milk and 26 to $37 \mathrm{~g} \mathrm{~L}^{-1}$ in cow milk. The levels of $\mathrm{k}-\mathrm{CN}$ and of $\alpha_{\mathrm{s} 2}-\mathrm{CN}$ in goat milk were 
similar to those in cow milk, though the latter presented higher levels of $\beta-C N$. The contents of $\alpha-C N$ and of $\beta$-LG are lower in goat milk (Greppiet et al., 2008).

In Table 2, the regression analysis of total protein percent ( $\beta-\mathrm{CN}$, goat $\alpha-\mathrm{CN}$ and $\operatorname{cow} \alpha-\mathrm{CN}$ ) plotted against percentages obtained for the mixtures with increasing levels of cow milk added to goat milk showed high correlation coefficients. Lines showed good fit, the best linearity was observed for cow $\alpha-C N\left(R=0.98\right.$ and $\left.R^{2}=0.96\right)$.

\section{TABLE 2 - LINEAR REGRESSION BETWEEN TOTAL PERCENT (\%) OF PROTEINS (B-CN, GOAT AND COW A-CN) AND INCREASING LEVELS OF COW MILK ADDED TO GOAT MILK USING UREA-PAGE}

\begin{tabular}{lccccc}
\hline Protein & Regression equation & $\mathrm{n}$ & $\mathrm{R}$ & $\mathrm{R}^{2}$ & $P$ \\
\hline$\beta-\mathrm{CN}$ & $\mathrm{y}=55.02-9.47 \mathrm{x}$ & 10 & 0.466 & 0.22 & 0.000 \\
Goat $\alpha-\mathrm{CN}$ & $\mathrm{y}=43.53-60.77 \mathrm{x}$ & 9 & 0.808 & 0.65 & 0.000 \\
Cow $\alpha-\mathrm{CN}$ & $\mathrm{y}=4.40+53.42 \mathrm{x}$ & 9 & 0.979 & 0.96 & 0.000
\end{tabular}

The high correlation of the protein fraction cow $\alpha_{\mathrm{s} 1}-\mathrm{CN}$ indicates that it is an efficient marker to detect and trace the electrophoretic profile of goat milk adulterated with cow milk. The statistical analysis using cow and goat milk as explanatory variables and total percentage as response variable showed that the explanatory variable with best fit to the response variable was cow $\alpha_{s 1}-C N$, since it presented the highest correlation, which indicates that the increase of this variable by one unit leads to a 53.42-fold increase in total percentage, with $n$ (number of samples) of 9 . This means that the more cow milk is added, the total protein percentage increases by a factor of 53.42 .

\subsection{SEPARATION AND CHARACTERIZATION OF THE MAIN GOAT AND COW MILK PRO- TEINS BY MICROFLUIDIC ELECTROPHORESIS}

\subsubsection{Qualitative Analysis}

The values quantified by the Bradford method were used to direct the calculations of sample dilutions so that the total protein concentration for this analysis was the standardized $(450 \mu \mathrm{g} \mathrm{mL}-$ 1). The electrophoretic separation and quantification of goat and cow milk proteins and mixtures of both milk was carried out by microfluidic capillary electrophoresis with laser-induced fluorescence (Nitsche, 2011). When compared with conventional electrophoresis, microfluidic electrophoresis is fast, easy to carry out, requires low amount of chemicals and samples (Anema, 2009; Butifoker et al., 2006; Greppi et al., 2008; Wu et al., 2008; Buffoni et al., 2011). This method allowed to quickly separate whey proteins ( $\alpha-L A, \beta-L G$, variants $A$ and $B$ ) from caseins $(\alpha-C N, \beta-C N$, and $k-C N)$ in cow and goat milk (Figure 3 ). The molecular weight of milk proteins was determined based on the migration times of the standard molecular weight ladder provided in the kit for each analysis, and in accordance to the migration time of them, the molecular weight of the samples are determined.

Goat and cow $\beta-\mathrm{CN}$ were the slowest caseins to migrate. Their microfluidic electrophoretic migration pointed out their similarity in molecular weight and migration times. On the other hand, cow $\alpha-\mathrm{CN}$ presented lower molecular weight $(37.3 \mathrm{kDa})$ and migration time $(31.46 \mathrm{~s})$ than the goat one ( $40.4 \mathrm{kDa}$ and $32.39 \mathrm{~s}$ respectively). Thus, cow $\alpha_{\mathrm{s} 1}-\mathrm{CN}$ has higher electrophoretic mobility (Fig. $4)$, since it has shorter migration time, compared with goat $\alpha_{s 1}-C N(T a b .3)$. This characteristic of cow $\alpha-C N$ is due to the larger hydrodynamic size acquired by caseins during electrophoresis, which makes these substances more negatively charged under alkaline conditions in SDS (Anema, 2009). 


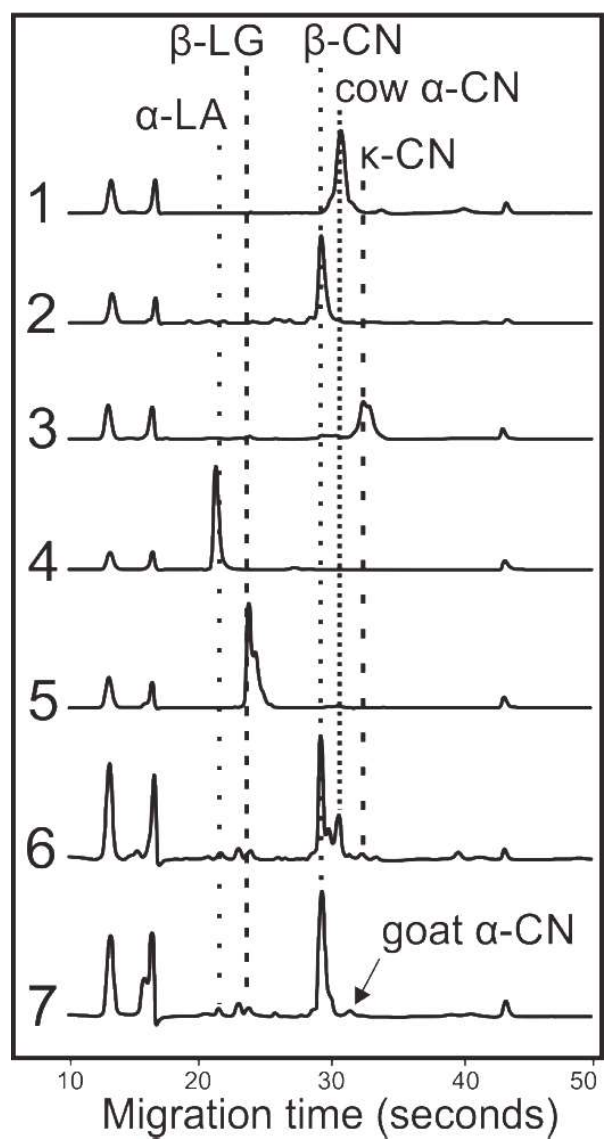

\section{FIGURE 3 - ELECTROPHORETIC PROFILE OF MILK PROTEINS OBTAINED BY MICROFLUIDIC ELECTROPHORESIS.}

1-5: PURIFIED PROTEINS FROM COW MILK (Sigma) $-\alpha_{\mathrm{S}^{-1}}, \beta-$, and $\mathrm{K}$-CASEIN, $\alpha$-LACTALBUMIN, $\beta$-LACTOGLOBULIN.

6- PURE COW MILK,

AND 7- PURE GOAT MILK.

In turn, k-CN was identified only in cow milk, with presented molecular weight of $43.7 \mathrm{kDa}$ and migration time of $33.46 \mathrm{~s}$ (Table 3). Cow $\alpha_{\mathrm{s} 1}-\mathrm{CN}$ profile obtained by microfluidic electrophoresis allowed the presence of cow milk at the concentration of $20 \%$ in goat milk (Figure 4). With respect to determine milk mixtures, urea-PAGE was more sensitive since its detection limit was $2 \%$ cow milk added Taking in account the present result, a possible alteration in the buffer of kit by replacing urea instead of SDS under reducing condition might give better results for this specific purpose.

In the molecular determination tests, all caseins analyzed through microfluidic electrophoresis presented higher molecular weight, compared to those analyzed using conventional SDS-PAGE (Table 3). As a rule, this migration, as observed for caseins, result from the trend to form aggregates or are due to other chemical properties, like glycolysis, phosphorylation pattern, and mainly hydrophobicity, which influences the structure of the protein and the interaction with the gel matrix during separation (Anema, 2009; Creamer and Richardson, 1984; Nitsche, 2011). This effect is especially visible for $\mathrm{k}-\mathrm{CN}$, since its molecular weight was $25 \mathrm{kDa}$, calculated by conventional SDS-PAGE, and 44kDa, obtained by microfluidic electrophoresis (Table 3). $\mathrm{k}-\mathrm{CN}$ was identified in the electropherogram only in cow milk, with molecular weight of $44 \mathrm{kDa}$ and migration time of 33.46 $\mathrm{s}$, while it was not detected in goat milk. The literature explains that this protein could overlap $\beta-L G$, if it had the expected molecular weight of $19 \mathrm{kDa}$, as observed in the SDS-PAGE technique (Nitsche, 2011). 


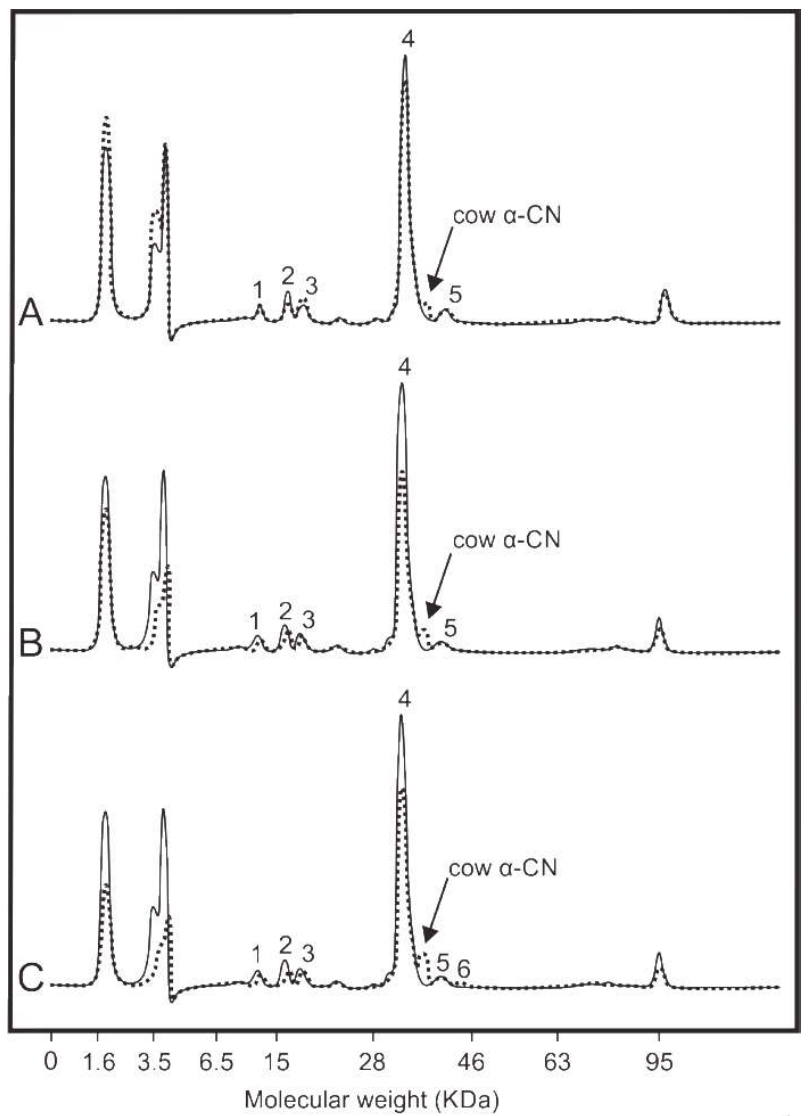

FIGURE 4 - COMPARISON OF ELECTROPHEROGRAMS FROM MIXTURE MILK SAMPLES (DOTTED LINE) AND PURE GOAT MILK (ENTIRE LINE) USING LAB-ON-ACHIP ELECTROPHORESIS.

MIXTURES CONTAINING 20\% (A), 35\% (B) AND 50\% (C) COW MILK IN GOAT MILK WERE HEREBY ANALYZED. 1- GOAT AND COW a-LACTALBUMIN

2- GOAT AND COW $\beta$-LACTOGLOBULIN A VARIANTS AND 3- B VARIANTS,

4- GOAT AND COW $\beta$-CASEIN, 5- GOAT $\alpha$-CASEIN AND COW $\alpha$-CASEIN (SETA).

TABLE 3 - MOLECULAR WEIGHT OF THE MAIN PROTEINS IN GOAT AND COW MILK BY MICROFLUIDIC ELECTROPHORESIS AND CONVENTIONAL

ELECTROPHORESIS (SDS-PAGE).

\begin{tabular}{|c|c|c|c|c|c|c|}
\hline & & Goat milk & & Cow $r$ & & \\
\hline Protein ${ }^{*}$ & Microfluidic & $\begin{array}{c}\text { Migration } \\
\text { time (s) }\end{array}$ & SDS-PAGE & Microfluidic & $\begin{array}{c}\text { Migration } \\
\text { time (s) }\end{array}$ & SDS-PAGE \\
\hline$\alpha-L A$ & $12 \pm 0.2$ & 22,37 & 12.34 & $12 \pm 0.15$ & 22,05 & 12.56 \\
\hline$\beta-L G$ & $18 \pm 0.3$ & 23,23 & 16.50 & $18 \pm 0.14$ & 24,4 & 16.63 \\
\hline$\beta-\mathrm{CN}$ & $33 \pm 0.8$ & 30,14 & 28.15 & $33 \pm 0.10$ & 30,13 & 28.03 \\
\hline$\alpha_{\mathrm{S} 1}-\mathrm{CN}$ & $40 \pm 0.5$ & 32,39 & 30.18 & $37 \pm 0.11$ & 31,46 & 29.94 \\
\hline$\kappa-C N$ & --- & & 26.21 & $44 \pm 0.13$ & 33,46 & 25.72 \\
\hline
\end{tabular}

"Molecular weight in $\mathrm{kDa}$ 
The separation of cow whey proteins was similar to that in goat milk. Peaks were clearly differentiated, where $\alpha$-LA migrated first (with $12 \mathrm{kDa}$ ) than $\beta$-LG, which revealed two genetic variants ( $A$ and $B$ ), with $16 \mathrm{kDa}$ and $18 \mathrm{kDa}$ (Figure 4). The estimated separation and molecular weight estimated for whey proteins using microfluidic electrophoresis were similar to the results obtained for cow (Anema, 2009; Costa et al., 2014) and buffalo milk (Buffoni et al., 2011). Studies using microfluidic electrophoresis and conventional techniques have reported the existence of genetic variants of $\beta-C N$ (Sgarbieri, 2005; Pesic et al., 2011).

\subsubsection{Quantitative Analysis}

As the values of $\mathrm{R}^{2}$ were distant from 1 , it demonstrated that the amount of this protein fraction has poor correlation with the increase in cow milk addition (i.e. low linearity). The data of cow $\alpha_{\mathrm{s} 1}-\mathrm{CN}$ produced a linear regression equation between total protein percentage and concentration of cow milk added to goat milk, with positive results. In Table 4, the correlation coefficient values obtained from the linear regression built with this protein were closer to $1\left(R=0.986\right.$ and $R^{2}=0.973$, indicating a great linearity of $\operatorname{cow} \alpha_{\mathrm{s} 1}-\mathrm{CN}$. Actually, it presented the highest correlation comparing to the other caseins investigated. In Table 5, a similar profile was observed for the linear regression calculated from the values of peak area against concentration of cow milk added to goat milk $(R=$ $\left.0.966, R^{2}=0.932\right)$. Cow $\alpha_{s 1}-C N$ presented the best results, the best line, the most aligned dots, and the highest statistical significance $(P=0.000)$ (Tables 4 and 5$)$.

TABLE 4 - LINEAR REGRESSION BETWEEN TOTAL PERCENT (\%) OF PROTEINS MAJOR CASEINS AND WHEY PROTEINS, AND GROWING LEVELS OF COW MILK ADDED TO GOAT MILK BY MICROFLUIDIC ELECTROPHORESIS.

\begin{tabular}{|c|c|c|c|c|c|}
\hline Protein & $\begin{array}{l}\text { Regression } \\
\text { equation }\end{array}$ & $\mathrm{n}$ & $\mathrm{R}$ & $\mathrm{R}^{2}$ & $P$ \\
\hline$\alpha-L A$ & $y=4.21-0.15 x$ & 9 & 0.009 & 0.003 & 0.000 \\
\hline$\beta-L G$ & $y=4.21-0.15 x$ & 9 & 0.057 & 0.068 & 0.000 \\
\hline$\beta-C N$ & $\begin{array}{c}y=74.502- \\
22.971 x\end{array}$ & 9 & 0.706 & 0.498 & 0.000 \\
\hline Cow $\alpha_{s 1}-C N$ & $\begin{array}{c}y=-1.356- \\
18.744 x\end{array}$ & 4 & 0.986 & 0.973 & 0.000 \\
\hline Goat $\alpha-C N$ & $\begin{array}{c}y=4.464- \\
2.869 x\end{array}$ & 8 & 0.322 & 0.104 & 0.000 \\
\hline Cow k-CN & $\begin{array}{c}y=-0.172+ \\
2.697 x\end{array}$ & 3 & 0.788 & 0.621 & 0.000 \\
\hline
\end{tabular}

The linear regression analysis revealed a narrow relationship between concentration of cow milk added to goat milk and relative proportions of the proteins of both milk types. High correlation coefficients may indicate that microfluidic electrophoresis is an effective tool to detect the presence of some proteins in goat and cow milk, and in mixtures thereof. Total percentage and peak area data showed that all proteins are correlated. In both cases, cow $\alpha_{\mathrm{s} 1}-\mathrm{CN}$ presented the best fit and the highest correlation with the two variables, indicating that when $\alpha_{s 1}-C N$ values (explanatory variable) increases by the factor of 1 , total percentage and peak area (independent variable) increase by factors of 18.74 and 35.57, respectively. The fact that the $n$ value for cow $\alpha_{s 1}-C N$ is the lowest underlines the notion that this protein is more significant, since the higher the $n$ value, the greater the chance of being significant, due to the higher number of degrees of freedom. This protein has the lowest $n$ value and is indeed the most significant. 


\section{TABLE 5 - LINEAR REGRESSION BETWEEN PEAK AREAS OF PROTEIN, MAJOR CASEINS AND WHEY PROTEINS, AND GROWING LEVELS OF COW MILK ADDED TO GOAT MILK BY MICROFLUIDIC ELECTROPHORESIS.}

\begin{tabular}{|c|c|c|c|c|c|}
\hline Protein & $\begin{array}{l}\text { Regression } \\
\text { equation }\end{array}$ & $\mathrm{n}$ & $\mathrm{R}$ & $\mathrm{R}^{2}$ & $P$ \\
\hline$\alpha-L A$ & $y=6.66-1.65 x$ & 9 & 0.058 & 0.069 & 0.000 \\
\hline$\beta-L G$ & $y=9.69-3.84 x$ & 9 & 0.172 & 0.183 & 0.000 \\
\hline$\beta-C N$ & $\begin{array}{c}y=157.343- \\
78.621 x\end{array}$ & 9 & 0.645 & 0.416 & 0.000 \\
\hline Cow $\alpha_{s 1}-C N$ & $\begin{array}{c}y=-2.956+ \\
35.575 x\end{array}$ & 4 & 0.966 & 0.932 & 0.000 \\
\hline Goat $\alpha-C N$ & $\begin{array}{c}y=10.502- \\
10.607 x\end{array}$ & 8 & 0.433 & 0.188 & 0.000 \\
\hline Cow k-CN & $\begin{array}{c}y=-0.239+ \\
5.372 x\end{array}$ & 3 & 0.701 & 0.491 & 0.000 \\
\hline
\end{tabular}

\section{CONCLUSIONS}

Microfluidic capillary electrophoresis exhibited relevant advantages, such as fast conduction and automation for determining electrophoretic profile and quantification of the main caseins in cow milk. Interestingly, $\mathrm{k}-\mathrm{CN}$ was not identified using this new approach, though. In contrast, concerning both whey proteins $\alpha-L A$ and $\beta-L G$, the results were better than the traditional methods and in addition could clearly identify the $A$ and $B$ variants of $\beta$-LG. In regard of mixtures of cow milk in goat milk, urea-PAGE showed a lower detecting limit than microfluidic capillary electrophoresis, indicating that the use of "lab-on-a-chip" technology in presence of urea buffer might will be the an interesting alternative for this purpose due to its advantage upon conventional methods. Therefore, microfluidic analytical methods, as the electrophoretic one presented hereby, show a great potential for cow and goat milk protein analysis.

\section{RESUMO}

\section{PRINCIPAIS PROTEÍNAS DE CABRA: SEPARAÇÃO E CARACTERIZAÇÃO POR ELETROFORESE MICROFLUÍDICA “LAB-ON-A-CHIP”}

Este trabalho apresenta o perfil eletroforético de amostras de leite caprino e suíno e suas misturas usando eletroforese microfluídica e convencional. A eletroforese microfluídica permitiu a separação completa das principais caseínas do leite, excetuando a k-caseína do leite de cabra. Além disso, as principais proteínas do soro foram separadas com perfeita distinçãodas variantes $A$ e $B$ da $\beta$-lactoglobulina. Comparando com SDS-PAGE, uma variação no peso molecular foi observada em todas as proteicas lácteas. Contudo, as variantes $A$ e $B$ da $\beta$-lactoglobulina não puderam ser isoladas utilizando SDS-PAGE. Embora ureia-PAGE não mostrou alta resolução entre as proteínas do soro de leite, as $\gamma^{-}, \mathrm{K}-, \beta$ - e $\alpha$-caseína foram claramente identificadas. Este método também mostrou um limite de deteç̧ão mais baixo de leite bovino nas amostras de mistura do que a eletroforese em chip. Em ambos os métodos, a linearidade mais alta obtida a partir da plotagem de percentagem total de cada fração proteica contra a concentração de leite de vaca foi observada usando a $\alpha_{s 1}$-caseína $\left(R^{2}=0,986\right.$ e $\left.R=0,973\right)$. Este resultado indica que a eletroforese microfluídica 
é uma ferramenta eficaz para detectar as principais proteínas do leite de cabra e de vaca, e suas misturas. A tecnologia de eletroforese microfluídica em chip pode complementar os métodos atuais para a análise de proteínas do leite, destacando a quantidade de reagentes e a separação das proteínas do soro, que apresentaram melhor resultados do que as técnicas de uréia e SDS-PAGE.

PALAVRAS-CHAVE: PROTEÍNAS DO LEITE, POLIACRILAMIDA, UREIA, CASEÍNAS, QUANTIFICAÇÃO.

\section{REFERENCES}

1 ANEMA, S. G. The use of "lab-on-a-chip" microfluidic SDS electrophoresis technology for the separation and quantification of milk proteins. International Dairy Journal. v. 19, p. 198-204, 2009.

2 BUFFONI, J. N.; BONIZZI, I.; PAUCIULLO, A.; RAMUNNO, L.; FELIGINI, M. Characterization of the major whey proteins from milk of Mediterranean water buffalo (Bubalusbubalis). Food Chemistry. v. 127, p. 1515-1520, 2011.

3 BUTIKOFER, U.; MEYER, J.; REHBERGER, B. Determination of the percentage of $\alpha$-lactalbumin and $\beta$-lactoglobulin of total milk protein in raw and heat treated skim milk. Milchwissenschaft. v. 61, p. 263-266, 2006.

4 COSTA, F. F.; BRITO, M.A.V.P.; FURTADO, M.A.M.; MARTINS, M.F.; OLIVEIRA, M. A.L.; BARRA, P.M.C.; SANTOS, A.S.O. Microfluidic chip electrophoresis Investigation of major milk proteins: study of buffers effects and quantitative approaching. Analytical Methods. v. 6, p. 1666-1673, 2014.

5 CREAMER, L.K.; RICHARDSON. T. Anomalous behavior of bovine $\alpha_{s 1}$ - and $\beta$-caseins on gel electrophoresis in sodium dodecyl sulfate buffers. Archives of Biochemistry and Biophysics. v. 234, p. 476-486, 1984.

6 DZIUBA, J.; NALECZ, D.; MINKIEWICZ, P. Reversed-phase high performance liquid chromatography on-line with the second and fourth derivative ultraviolet spectroscopy as a tool for identification of milk proteins. Analytica Chimica Acta. v. 449, p. 243-252, 2001.

7 EGITO, A. S.; ROSINHA, G. M. S.; LAGUNA, L. E.; MICLO, L.; GIRARDE, J. M.; GAILLARD, J. L. Método eletroforético rápido para deteç̧ão da adulteração do leite caprino com leite bovino. Arquivo Brasileiro de Medicina Veterinária e Zootecnia. v. 58, p. 932-939, 2006.

8 FURTADO, M. M. Detection of cow milk in goat milk by polyacrylamide gel electrophoresis. Journal of Dairy Science. V. 66, p. $1822-1824,1983$.

9 GARCíA-OtERO, N.; BARCIELA-ALONSO, M. C.; MOREDA-PIÑEIRO, A.; BERMEJO-BARRERA, P. Study of extraction procedures for protein analysis in plankton samples by OFFGEL electrophoresis hyphenated with Lab-on-achip technology. Talanta. v. 115, p. 631-641, 2013.

10 GOETZ, H.; KUSCHEL, M.; WULFF, T.; SAUBER, C.; MILLER, C.; FISHER, S.; WOODWARD, C. Comparison of selected analytical techniques for protein sizing, quantification and molecular weight determination. Journal of Biochemical and Biophysical Methods. v. 60, p. 281-293, 2004.

11 GOULDSWORTHY, A. M.; BANKS, J. M.; LAW, A. J. R.; LEAVER, J. Casein degradation in Cheddar cheese monitored by capillary electrophoresis. Milchwissenschaft. v. 54, p.620-623, 1990.

12 GREPPI, G. F.; RONCADA, P.; FORTIN, R. Protein Components of Goat's Milk. In: PULINA, G.; CANNAS. A. Dairy Goats Feeding and Nutrition. Bologna: CAB International, 2008. p. 71-94.

13 HINZ, K.; O'CONNOR, P. M.; HUPPERTZ, T.; ROSS, R. P.; KELLY, A. L. Comparison of the principal proteins in bovine, caprine, buffalo, equine and camel milk. Journal of Dairy Research. v. 79, p. 185-191, 2012.

14 LI, H-Y.; DAURIAC, V.; THIBERT, V.; SENECHAL, H.; PELTRE, G.; ZHANG, X-X.; DESCROIX, S. Micropillar array chips toward new immunodiagnosis. Lab on a Chip. v. 10, p. 2597-2604, 2010.

15 BRADFORD, M. A Rapid and Sensitive Method for the Quantitation of Microgram Quantities of Protein Utilizing the Principle of Protein-Dye Binding. Analytical Biochemistry. v. 72, p. 248-254, 1976.

16 MARLETTA, D.; CRISCIONE, A.; BORDONARO, S.; GUASTELLA, A. M.; D'URSO, G. Casein polymorphism in goat's milk. Lait. v. 8, p. 491-504, 2007.

17 MAYER, H. K.; BURGER, J.; KAAR, N. Quantification of cow's milk percentage in dairy products-a myth? Analytical and Bioanalytical Chemistry. v. 403, p. 3031-3040, 2012.

18 NITSCHE, R. Milk protein analysis with the Agilent 2100 Bioanalyzer and the Agilent Protein 80 kit, p. 7. Agilent Technologies, Inc. Application Note 5990-8125EN, 2011.

19 PARDO, M. F.; NATALUCCI, C. L. Electrophoretic Analysis (Tricine-SDS-PAGE) of Bovine Caseins. Acta Farmaceutica Bonaerense. v. 21, p. 57-60, 2002. 
20 PATEL, H. A.; ANEMA, S. G.; HOLROYD, S. E.; SINGH, H.; CREAMER, L. K. Methods to determine denaturation and aggregation of proteins in low-, medium- and high-heat skim milk powders. Lait. v. 87, p. 251-268, 2007.

21 PESIC, M.; BARAC, M.; VRVIC, M.; RISTIC, N. et al. Qualitative and quantitative analysis of bovine milk adulteration in caprine and ovine milks using native-PAGE. Food Chemistry. v. 125, p. 1443-1449, 2011.

22 POITEVIN, M.; SHAKALISAVA, Y.; MISERERE, S.; PELTRE, G.; VIOVY, J. L.; DESCROIX, S. Evaluation of microchip material and surface treatment options for IEF of allergenic milk proteins on microchips. Electrophoresis. v. 30, p. 42564263, 2009.

23 SALEM, S. A., EL-AGAMY, I., SALAMA, F. A., ABO-SOLIMAN, N. H. Isolation, Molecular and Biochemical Characterization of Goat Milk Casein and its Fractions. Tropical and Subtropical Agroecosystems. v. 11, p. 29-35. 2009.

24 SGARBIERI, V. C. Revisão: Propriedades Estruturais e Físico-Químicas das Proteínas do Leite. Brazilian Journal of Food Technology. v. 8, p. 43-56, 2005

25 RBÁN, G.; PÉREZ, N.; FRESÁN, C.; GONZÁLEZ, C.; VEJA, S.; GUTIÉRREZ, R.; DÍAZ, G. Detección de adulteración com suero de quesería em leches fluidas mexicanas mediante eletroforesis em gel de poliacrilamida (SDS-PAGE). Revista de Salud Animal. v. 24, p. 60-64, 2002.

26 VELOSO, A. C. A.; TEIXEIRA, N.; FERREIRA, I. M. P. L. V. O. Separation and quantification of the major casein fractions by reverse high-performance liquid chromatography and urea-polyacrylamide gel electrophoresis. Detection of milk adulterations. Journal of Chromatography A. v. 967, p. 209-218, 2002.

27 WU, D.; QIN, J.; LIN, B. Electrophoresis separations on microfluidic chips. Journal of Chromatography A. v. 1184, p. 542-559, 2008.

\section{ACKNOWLEDGEMENTS}

The authors acknowledge Coordenação de Aperfeiçoamento de Pessoal de Nível Superior (PNPD/CAPES) for financial support and fellowships of Alessa Siqueira de Oliveira dos Santos.

Funding for this study was provided by Embrapa/ Monsanto Agreement (02-11-04-005-0000). A. S. O. SANTOS has a PNPD/ CAPES scholarship, G. N. FOGAÇA has a Embrapa/ Monsanto scholarship, and M. F. MARTINS has a CNPq scholarship. 